\title{
THE EUROPEAN POLICY ABOUT TRAINING STUDENTS OF LANGUAGES
}

\author{
Özcan İlginç Demirsu ${ }^{1^{*}}$ \\ ${ }^{1}$ Near East University Graduate School of Educational Sciences, PhD Candidate \\ ozcan.demirsu@neu.edu.tr
}

Correspondence: ozcan.demirsu@neu.edu.tr; Tel.:

\begin{abstract}
The European Union (EU) is a political and economic union which comprises 28 member states primarily located in Europe. It works for its members to promote peace, its values and the well-being of its citizens. Offer freedom, security and justice without internal borders. It also aims to enhance economic, social and territorial cohesion and solidarity among EU countries. Consequently, education becomes one of the most important issues in Europe that is urged on. Especially, language education has a key position. Learning language means developing a multicultural identity and knowing about different cultures. In order to provide a better language education, training prospective language teachers in accordance with current educational principles has a significant role. European Commission has introduced several documents for teaching, learning, assessing and teacher training in Europe according to the European Educational Policy. This study examines the documents developed for prospective language teachers in order to identify the European policy about training European language teachers. In the study, qualitative method based on document analysis was used. The results of the study were discussed with relevant literature.
\end{abstract}

Keywords: European policy, training language teachers, language teaching, European documents

\section{Introduction}

Education is one of the most, especially language education, significant issue in both around the world and European Union. When it is considered from the perspective of language teaching and learning, it can be said that there have been exceeding changes in the area of language teaching. Nowadays, learning a language such as English has become as necessity rather than need. This is because people now need to communicate with people around the world with the help of the World Wide Web to share things with each other that they need to learn languages. Multilingualism policies in European Union suggests that "Languages unite people, render other countries and their cultures accessible, and strengthen intercultural understanding. Foreign language skills play a vital role in enhancing employability and mobility." (Why multilingualism is important?, n.d.) Therefore, the European Union is working on this issue and the member states are enhancing that cooperation is needed for multilingualism.

On the other hand, European Commission is collaborating with national governments to reach their goal which is all citizens should learn at least two languages and they should start learning at the early age." (Why multilingualism is important?, n.d.) To achieve this goal there should be well educated language teachers to educate the citizens of the European Union. As a result, "the education of foreign language teachers is of increasing importance because their key role in improving foreign language learning awakening learners' interest in 
languages. Language teachers play a major part in achieving European Union's objective that all EU citizens should have linguistic competence in their own mother tongue and two other languages." (EPLTE).

\subsection{Research Model}

There are not many researches on European policies of student teachers of languages. Most of the studies discuss the importance of learning and teaching a foreign language. Firstly it is stated that multilingualism and the development of European citizens' linguistic abilities are at the heart of the EU's mission (Saville \& Eugenio, 2016). This is the reason why language teacher education is an essential issue in European Union. The education of foreign language is of increasing importance because of their key role in improving foreign language learning and awakening learners' interest in languages (Kelly \& Grenfell, 2007). It is also known that learning a foreign language overcomes the barriers of communication (CEFR, 2001). As a result of these, teachers play a major role in education. Teachers have a key role in developing students' skills in foreign languages (Key Data on Teaching Languages at School in Europe, 2017). Therefore, language teachers play a significant role in language teaching in achieving the European Union's aims. (EPLTE, 2007).

Preliminary teacher education is the first crucial step in a teacher's professional journey. It establishes the foundations of a professional mind-set and provides the new teacher a fundamental toolbox that can make the learning more meaningful which happens in the classroom. It also offers the opportunity to experiment in a real school. In this environment teachers can discuss, reflect and share ideas or experiences with peers and experts. Moreover, building awareness of complexities of teaching helps them to develop planning skills and adjusting to specific situations and needs (Caena, 2014). Preliminary teacher education is an intensive knowledge that requires student teachers to be both learners and teachers concurrently. They are supported in how to teach and to support learners in how to learn. It is compelling and it needs analysing, questioning and reviewing ideas in the environment of practice. It includes the whole person attitudes, beliefs and emotions. Teachers themselves are the primary resources (Caena, 2014) In the light of these ideas a portfolio which is called EPOSTL is created. It is a document intended for students undergoing their initial teacher education which encourages them to reflect on the didactic knowledge and skills necessary to teach languages, helps them to assess their own didactic competences and enables them to monitor their progress and to record their experiences of teaching during the course of their teacher education (Newby et al., 2007) The role of teachers is really important since multilingualism is important in European Union.

\subsection{Purpose of the Study}

In many previous studies language learning in different contexts, multilingualism and teacher education in European Union are mentioned. However, there are not any studies about the policies in European Union for student teachers of languages. Hence, the study determined to study the policies in European Union for student teachers of languages. The purpose of the study is to examine the policies in more depth to understand what the student teachers should do to develop language teaching and learning skills. The major research problem of this study is as follows:

"What are the European policies about training student teachers of language?" 


\section{Method}

In this study qualitative method is used. "Qualitative method can be described as a method which qualitative methods used like observations, interviews and documents are analyzed, qualitative process is used to reveal senses and events in their natural environment in realistic and holistic way." (Yildirim\& Simsek, 2011). According to Kus (2013), the main characteristics of qualitative research is to see the point of views, reveal the semantic world and to see the world with the eyes of the participants. Therefore, the present study was conducted with qualitative method design. Qualitative research method design includes different ways. In this method document analysis is used and various documents are analysed to reach the aim of the study. The study aimed to have the better understanding the policies in European Union for student teachers of languages.

\section{Results and Discussion}

The findings of the study are given in the following figure.

\begin{tabular}{|c|c|c|c|}
\hline Number & Policy Statements & Text & Text Source \\
\hline 1 & $\begin{array}{l}\text { Foreign Language Teacher } \\
\text { Education in Europe should be in } \\
\text { the first place in order of } \\
\text { importance. }\end{array}$ & $\begin{array}{l}\text { The education of } \\
\text { foreign language } \\
\text { teachers is of } \\
\text { increasing } \\
\text { importance because } \\
\text { of their key role in } \\
\text { improving foreign } \\
\text { language learning }\end{array}$ & EPLTE page. 4 \\
\hline 2 & $\begin{array}{l}\text { The teachers actions and attitudes } \\
\text { should be taken in consideration in } \\
\text { foreign language teaching }\end{array}$ & $\begin{array}{l}\text { Teachers should } \\
\text { realise that their } \\
\text { actions, reflecting } \\
\text { their attitudes and } \\
\text { abilities, are most } \\
\text { important part of the } \\
\text { environment for } \\
\text { language learning }\end{array}$ & CEFR, page. 144 \\
\hline 3 & $\begin{array}{l}\text { Foreign Language Teacher } \\
\text { Education should integrate the } \\
\text { academic study and the practical } \\
\text { experience }\end{array}$ & $\begin{array}{l}\text { During language } \\
\text { teacher education the } \\
\text { practical experience } \\
\text { of teaching in the } \\
\text { classroom and the } \\
\text { academic study of } \\
\text { pedagogical theory } \\
\text { are the subject area } \\
\text { to be treated } \\
\text { holistically as they } \\
\text { interact with one } \\
\text { another. }\end{array}$ & EPLTE page. 5 \\
\hline 4 & Foreign Language Education should & The Common & CEFR page. 1 \\
\hline
\end{tabular}




\begin{tabular}{|c|c|c|c|}
\hline & be related to CEFR principles & $\begin{array}{l}\text { European } \\
\text { Framework is } \\
\text { intended to } \\
\text { overcome the } \\
\text { barriers to } \\
\text { communication } \\
\text { among professionals } \\
\text { working in the field } \\
\text { of modern languages } \\
\text { arising from the } \\
\text { different educational } \\
\text { systems in Europe. It } \\
\text { provides the means } \\
\text { for educational } \\
\text { administrators, } \\
\text { course designers, } \\
\text { teachers, teacher } \\
\text { trainers, examining } \\
\text { bodies, etc., to reflect } \\
\text { on their current } \\
\text { practice }\end{array}$ & \\
\hline 5 & $\begin{array}{l}\text { Foreign Language Education should } \\
\text { be based on different language } \\
\text { teaching methodologies }\end{array}$ & $\begin{array}{l}\text { Trainee teachers } \\
\text { learn about different } \\
\text { language teaching } \\
\text { methodologies and } \\
\text { can use them to } \\
\text { achieve different } \\
\text { learning outcomes }\end{array}$ & EPLTE page. 18 \\
\hline 6 & $\begin{array}{l}\text { Foreign Language Teacher } \\
\text { Education should be continuous } \\
\text { learning }\end{array}$ & $\begin{array}{l}\text { Training in the } \\
\text { importance of life - } \\
\text { long learning }\end{array}$ & EPLTE page. 44 \\
\hline 7 & $\begin{array}{l}\text { In Foreign Language Education } \\
\text { European Language Portfolio } \\
\text { should be used from the first stage }\end{array}$ & $\begin{array}{l}\text { Trainee teachers } \\
\text { learn about ELP } \\
\text { from the earliest } \\
\text { stages of their initial } \\
\text { teacher education }\end{array}$ & EPLTE page. 38 \\
\hline 8 & $\begin{array}{l}\text { During Foreign Language Teacher } \\
\text { Education EPOSTL should be used } \\
\text { to record the experiences of trainee } \\
\text { teachers }\end{array}$ & $\begin{array}{l}\text { It will encourage you } \\
\text { to reflect on your } \\
\text { didactic knowledge } \\
\text { and skills necessary } \\
\text { to teach languages, } \\
\text { helps you to assess } \\
\text { your own didactic } \\
\text { competences and } \\
\text { enables you to } \\
\text { monitor your } \\
\text { progress and to } \\
\text { record your }\end{array}$ & EPOSTL page. 5 \\
\hline
\end{tabular}




\begin{tabular}{|l|l|l|l|}
\hline & $\begin{array}{l}\text { experiences of } \\
\text { teaching during the } \\
\text { course of your } \\
\text { teacher education. }\end{array}$ & \\
\hline
\end{tabular}

Figure 1. Findings

As it is seen in the first part of the table, foreign language teacher education is a significant issue that should be taken in consideration at first place. This is because foreign language teachers has an important role in improving and awakening the foreign language education (EPLTE, 2004). In the second part of the table it is seen that the foreign language teachers' actions and attitudes should be taken into consideration as they are substantial part of language learning environment (CEFR, 2001). In the third part of the table it is shown that foreign language education should integrate the academic study and practical classroom experience. As, pedagogical study and classroom teaching experience should be treated as a whole (EPLTE, 2004). In the fourth part of the table it is seen that foreign language teacher education should be related to CEFR principles. The CEFR is a framework that is designed to help administrators, course designers, teachers, teacher trainers and examiners to design their curriculum, syllabus, teaching methods and assessments (CEFR, 2001). In addition to these, in the fifth part of the table it is shown that foreign language teacher education should be based on various teaching methods so that teachers can use them to achieve different outcomes of their teaching.

As it is seen in the sixth part of the table, foreign language teacher education should be continuous in order to catch up with new methods and techniques in teaching (EPLTE, 2004). In the seventh part of the table it is seen that in foreign teacher education ELP should be learned from the first stage of initial teacher education. "Trainee teacher should understand how ELP is structured in three parts (language passport, language biography and dossier) and recognise that its proper compilation is an ongoing process." (EPLTE, 2004, p. 38) Finally, in the last part of the table it is shown that during foreign language education EPOSTL should be used to record trainee teachers' experiences in teacher education to encourage them to reflect on their didactic knowledge and skills necessary to teach languages and also it helps to assess their own didactic competences and enables them to monitor their progress (EPOSTL, 2007).

\section{Conclusion}

In conclusion, in European Union multilingualism has an importance place as members of European Union aim is to have European citizens who have linguistic competence in both their native language and two other languages. Therefore, the importance of foreign language teachers emerges. Foreign language teachers are people who will improve foreign language learning and awake learners' interest to language learning. For this reason, there is a need for qualified foreign language teachers to take part in achieving the European Union's aims. In order to have qualified foreign language teachers there should be a good teacher education. Students teachers of foreign languages should be educated well before they start teaching.

First of all, they should have a good pedagogical study of foreign languages. They should learn things like teaching methodologies, preparing lessons, preparing assessment, classroom 
management, and action research in other words learning to identify particular issue or a problem while teaching and so on. Besides these, academic study should be integrated with real classroom experience to learn about real world. It is obvious that foreign language teacher education is really important.

From the perspective of European Union all of these should be based on some policies. As it is known CEFR is a framework which guides administrators, teachers, and trainee teachers, examiners about learning, teaching and assessment. Therefore, principles of CEFR should be taken as a basis. Then, European Profile for Language Teacher Education should be used to familiarize the trainee students of foreign languages about the structure, strategies and skills and values of teacher education. This profile should also be used by teacher educators when they want show some of initiatives about European Union's language teacher education. 


\section{References}

Burkert, A., \& Schwienhorst, K. (2008). Focus on the student teacher: The European portfolio for student teachers of languages (EPOSTL) as a tool to develop teacher autonomy. International Journal of Innovation in Language Learning and Teaching, 2(3), 238-252

Caena, F. (2014). Initial Teacher Education in Europe: An Overview of policy issues. European Commission, ET2020 Working Group of School Policies

Common European Framework of Reference for Languages: Learning, Teaching, Assessment. (2001). Language Policy Unit, Strasbourg.

European Commission/EACEA/ Eurydice. (2017). Key Data on Teaching Languages at School in Europe. Luxembourg: European Union.

Kelly, M., \& Grenfell, M. (2004). European Profile For Language Teacher Education: A Frame Reference. England: University of Southampton.

Kus, E. (2003). Nicel-nitel arstirma teknikleri. Ankara: Ani Yayincilik.

Newby, D. (2007). European portfolio for student teachers of languages: A reflection tool for language teacher education. Strasbourg: Council of Europe.

Saville, N., \& Eugenio, E. G. (2016). Research for Cult Committee-European Strategy on Multilingualism-Policy and Implementation at the EU Level. Brussels: European Parliament

Yildirim, A., \& Simsek, H. (2011). Sosyal bilimlerde nitel arastirma yontemleri. Ankara: Seckin Yayincilik. 